\title{
進行直腸癌，および局所再発直腸癌に 対する仙骨合併骨盤内臟器全摘術
}

\author{
一一適応，手術手技と 6 症例の報告——
}

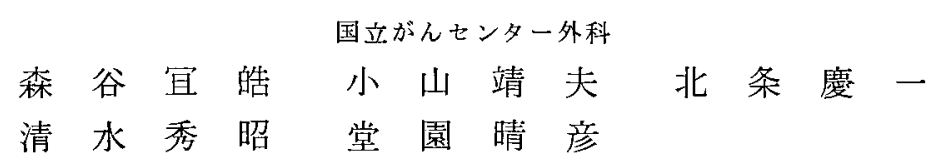

\begin{abstract}
直腸癌術後再発の半数近くは，局所再発であり，骨盤内臟器全摘術を含む再切除術を施行しても，骨盤壁 への癌巣の遣残により，姑息切除に終える症例が多い，また局所進展高度な原発直腸癌の一部には，すでに 骨盤壁に浸潤の認められる症例もある．原発直腸癌 2 例，局所再発直腸癌 4 例の骨盤壁浸潤例に仙骨合併骨 盤内臟器全摘術を施行し，本術式の具体的手技と術後各種機能障害に関連する諸問題についても症例にもと ずき検討した。

直腸癌骨盤壁再発を，側方骨盤壁再発と後方骨盤壁再発に分類した。骨盤内葴器全摘術に対する適応基準 に加え，後方骨盤壁再発例に，本術式の真の適応があると考えられた，手術侵襲は過大なものであるが，臨 床症状の改善をもたらし，局所進展高度な原発直腸癌や，後方骨盤壁再発直腸癌に対しては根治性の高い術 式であると考えられた.
\end{abstract}

索引用語 : 局所再発, 仙骨合侀筲盤内臟器全摘術, 直晹癌, 骨盤内臟器全摘術

\section{1. はじめに}

准行直腸癌に対する Miles 術後の再発例の半数近く は局所再発である.これら局所再発の多くは，骨盤壁に 浸潤する進展を示し，その結果，坐骨神経痛や下部尿管 閉塞等を続発する. 私共は再発癌の根治的治療の主役も また, 骨盤内臟器全摘術を含む再切除と加療療法, 小線 源治療などの強力な合併補助療法の採用であると考え， 積極的行行っている ${ }^{1,2)}$ ，尿路变更術を含む再切除は坐 骨神経痛，下部尿管閒塞などに対しては，十分な勃果を もたらしているが, aggressive な治療にもかかわらず， その遠隔成績は必ずしも良好なものとはいえない。

一方，局所進展高度な原発直腸癌や局所再発直腸癌で は，骨盤壁の合併切除により初めて根治切除可能な症例 にも遭遇する．そこで今回，原発直腸癌 2 例と直腸癌術 後局所再発 4 例に仙骨合併骨盤内藏器全摘術を施行した ので，6症例の報告，手術手技の実際，さらに本術式の 適応につき検討を加え報告する.

\section{2. 対象と方法}

対象 6 症例のうち，症例 $1 ， 2$ は原発直腸癌，残り 4
例は直腸癌術後局所再発例であり, うち症例 $3 ， 4,5$ は Miles 術後再発例で，いずれも初回手術は他院にて行わ れた（表 1 ). 症例 6 は低位前方切除後の再発例である. すべて男性で, 年齢は 49 歳から 64 歳, 平均57歳であっ た. 術前化学療法は, 症例 4, 5 に行われ, 症例 4 、には Methraxate $1.8 \mathrm{gr}$, UFT $1.8 \mathrm{gr}$, 症例 5 には; Mitomycin C 40mg, Tegafur 26gr の投与内容であった. 一 方術前放射線治療法, 症例 $2 ， 4$ 亿行われ，症例 2 沙術

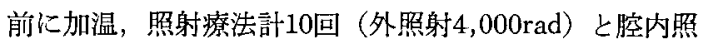
射2,000 rad 施行例である。一方，症例 4 は，7,300 rad 外照射例である. 臨床症状は, 肛門, 尾骨; 仙骨領域に 対象 6 例いずれにも疼痛が認められている：原発直腸癌 を除く再発 4 例の再発までの期間注最短 2 年 9 力月, 最 長 6 年 8 力月, 平均 3 年 9 力月,゙あった.

\section{手術手技}

腹部操作

砕石位にて広域正中切開をおき, 肝転移, 腹部大動脈 周团リンパ節転移，さらに腹膜播種なきこと, つまり病 栄が骨盤内に限局していることを確認する，原発直腸癌 であれば，下腸間膜動脈起始部を含めた腹部大動脈周囲 


\begin{tabular}{|c|c|c|c|c|c|c|c|c|}
\hline 症例 & 年齢 / 性 & $\begin{array}{l}\text { 初回手術時 } \\
\text { 部位, 病期 }\end{array}$ & $\begin{array}{l}\text { 初回手術日と } \\
\text { 再発迄の期間 }\end{array}$ & 症 状 & $\begin{array}{c}\text { CEA } \\
(<5.0 \mathrm{ng} / \mathrm{ml})\end{array}$ & 術 前 照 射 & 組蟣型 & その他 \\
\hline 1 & $63 / M$ & $\begin{array}{c}R b \\
\text { Dukes } B\end{array}$ & ${ }^{\text {原発 }} / 83$ & $\begin{array}{l}\text { テネスム有 } \\
\text { 肽 門 痛 }\end{array}$ & 740 & & 中分化腺癌 & \\
\hline 2 & $64 / M$ & $\stackrel{R b}{\text { Dukes } C}$ & $\begin{array}{l}\text { 原発 } \\
10 / 83\end{array}$ & 粘血便 & 3.6 & 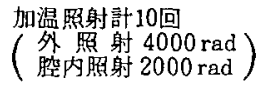 & 高分化腺㿋 & \\
\hline 3 & $49 / \mathrm{M}$ & $\begin{array}{c}\text { Rb } \\
\text { Dukes B }\end{array}$ & $\begin{array}{l}2 \text { 年 } 9 \text { 力月 } \\
7 / .81\end{array}$ & 尾，仙骨痛 & 161 & & 中分化腺癌 & \\
\hline 4 & $54 / \mathrm{M}$ & $\stackrel{\text { Rb }}{\text { Dukes } B}$ & $\begin{array}{l}6 \text { 年 } 8 \text { 力月 } \\
5 / 75\end{array}$ & 尾，臂部痛 & 3.4 & 外 照 射 $7333 \mathrm{rad}$ & 粘 液 痋 & $\begin{array}{c}\text { 会陰再発褁摘除 } \\
2 / 83\end{array}$ \\
\hline 5 & $51 / \mathrm{M}$ & $\begin{array}{c}\mathrm{Rb} \\
\text { Dukes } \mathrm{B}\end{array}$ & $\begin{array}{l}3 \text { 年 } \\
5 / 180\end{array}$ & 尾, 臂部痛 & 2.4 & & 高分化腺癌 & 肝右葉垫 82 除 \\
\hline 6 & $60 / M$ & $\begin{array}{c}R a \\
\text { Dukes C }\end{array}$ & $\begin{array}{l}3 \text { 年 } \\
5 / \cdot 80\end{array}$ & 小腸会陰瘦 & 16.7 & & 中分化腺癌 & $\begin{array}{c}\text { 右肺下葉切除 } \\
\text { 骨盤内䏵器全摘 } \\
10 / ' 82\end{array}$ \\
\hline
\end{tabular}

を郭清しながら大動脈分岐部に至る，一方再発癌であれ ば，左右尿管を確認の後, 大動脈分岐部より剝離を開始 する，総腸骨動脈より内外腸骨動静脈根部を露出する. 外腸骨動静脈の血管鞘に沿い腸腰筋筋膜を露出しなが ら，そけい勒帯に至るまでの脂肪織を内下方に郭清し， 内方に位置する閉鎖神経，同動静脈，更に下方に位置す る腰仙骨ならびに第一仙骨神経を確認し，内腸骨血管外 側に至る.この操作により閉鎖腔内にある脂肪織，およ びリンパ系が摘除側に付く，内腸骨血管䩗に沿う剝離を 内外嵲側上り尾側汇向って進め, 上殿動脈静脈分岐末梢 側で内腸骨血管を transfixing sutureにより結禁切断 し，末梢側を索引しながら仙骨神経叢の間を貫通する下 殿動脈静脈，内陰部動静脈などの各分岐をていねいに結 禁切断してゆく、前回の手術で側方郭清が行われていた り会陰創感染の併発，あるいは術前放射線治療例では， 内腸骨血管分岐, 特に静脈系の処理に当っては怒耐と慎 重な展開を要する. 仙骨前面の剥離注電気入 スにて行 う. 岬角を示標仙仙骨切断レベルを決定し，仙骨左右縁 を十分露出しておく(図1).

次いで前面の展開にらつる. 後腹膜切開を延長し, 精 管（子宮円索）を結禁切離し，膀胱頂部に至る. 膀腅前 面を坨骨後面に沿い剝離し膀胱頸部の静脈灇に達する. 尿道㧍よび静脈叢の处理は仙骨術式にて行うが，両側内 腸骨静脈処理後に押いては, 膀胱頙部静脈叢は著しく怒 張しており，慎重な展開が必要と成る. 以上で腹腔側に よる摘除操作を終了するが次いで回腸導管を造設する. 症例 3 亿注，一側合流尿管皮虚瘘術を造設したが，残り 5 例はいずれも回腸導管が造設されている.

体位変換（図 2)

正中創を仮閉腹の後，体位を Jacknife Position 之 する. 股関節を屈曲開排し，頭部を低位にするが，この 際 Voelecker-Werthues 体位の如く胸骨上部と左右腸骨

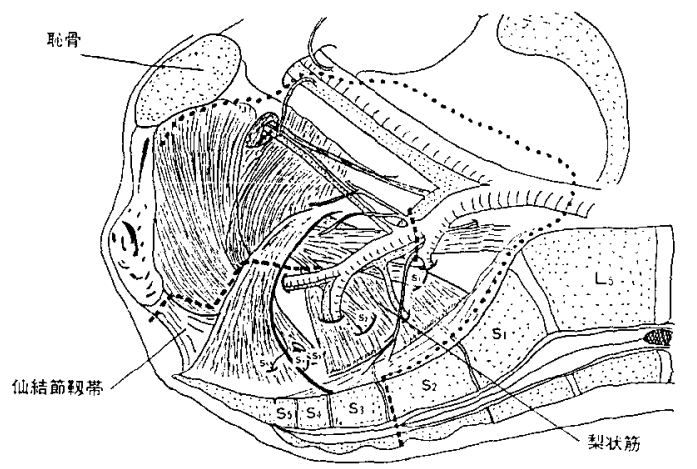

切除線 $(\cdots \cdots)$ と郭清範国 $(\cdots \cdots)$

図 1

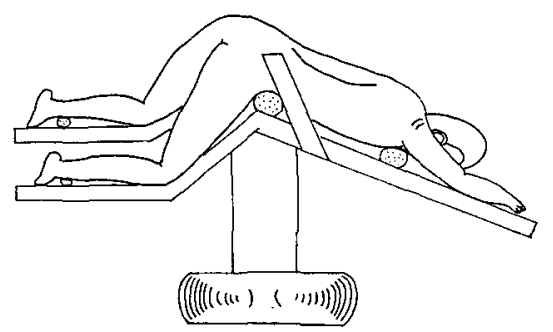

図 2 Jackknife position

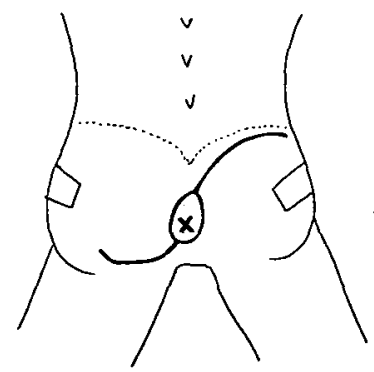

図 3 仙骨合件切除時の皮虔切開 
稜で体重を支持することが肝要である，不確実な Jacknife Position では, 腹腔内圧上昇にもとうく下大静脈 支配領域の静脈圧上昇を来たす。特に肥満体や内腸骨血 管合併切除例では静脈性出血を招き，仙骨術式のメリッ トが帳消しとなる。

会陰, 仙骨部操作

通常, 図 3 の如く左側の上後腸骨棘下内側より会陰創 㓔痕を広く摘除側につけ， $\mathrm{S}$ 字状に右殿部譬に至るまで の皮切を加える. 大殿笳, 中殿筋, 仙骨背面も露出の 後, 仙骨起始部にて大殿筋及び中殿筋側に勒帯を付着す る型で仙骨より切離する. 後の後方骨盤底形成に好都合 となる．次いで坐骨結節を確認の後仙結節靶帯を坐骨結 節近傍で切離すると内閉鎖筋が確認出来る. 坐骨結節と 大転子間で, さらに坐骨神経, 梨状筋, 双子筋を確認し, 仙䊂靭帯の切離にうつる (写真 1 ).この靶帯は, 強勒で あり, 示指にて走行を確認しながら切断すると, 梨状笳

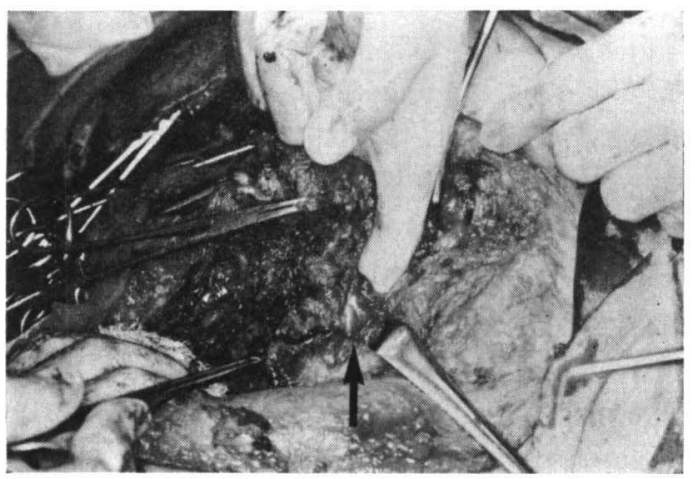

写真 1 症例 3

仙骨側操作，示指を右側仙棘勒帯に通していると ころである。

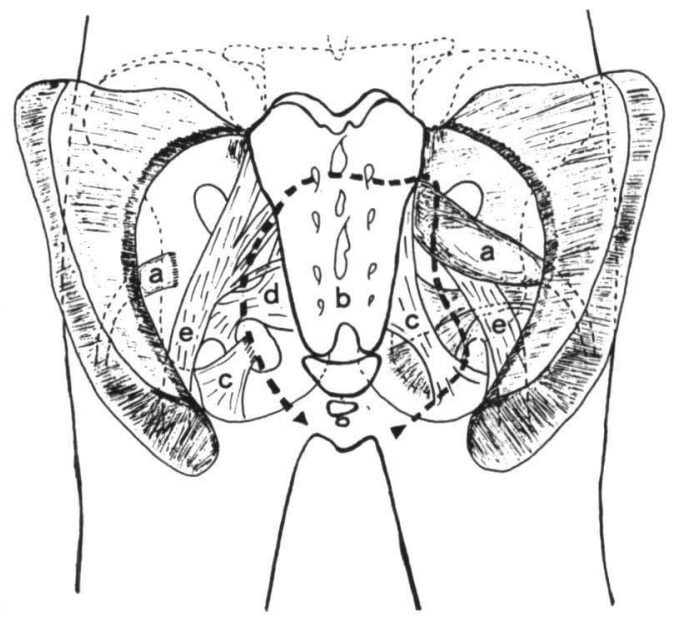

a. 梨状筋 b. 仙骨 c. 仙結節䩡帯 d. 仙棘勒带 e. 坐骨神経

図 4 仙骨術創と切除範囲
及び坐骨神経の下縁に達する。坐骨神経を注意しながら 梨状筋を大転子寄りで切離する (図 4 ). 仙骨は, 骨相互の 連続性と仙結節, 仙䊂靶帯の二つの強力な勒帯により固

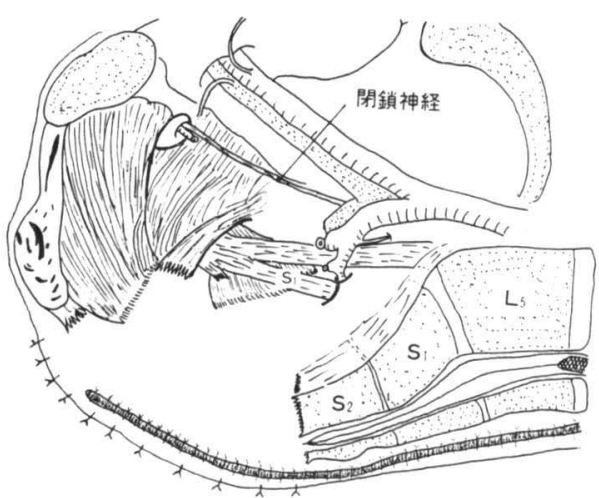

図 5 切除終了時の骨盤内と大㯏筋による骨 盤底形成

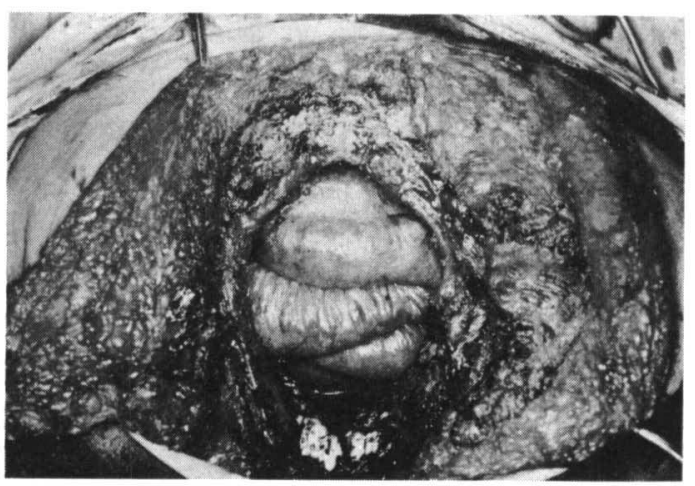

写真 2 症例 4

仙骨側摘除操作操作終了時の術中写真

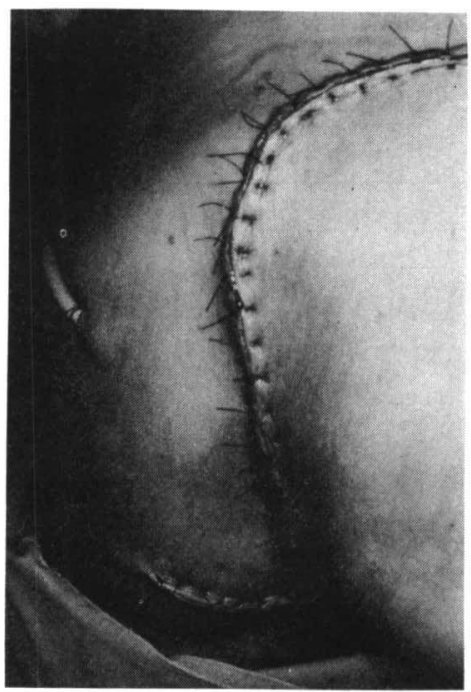

写真 3 症例 4

仙骨側皮膚縫合終了時の術中写真 


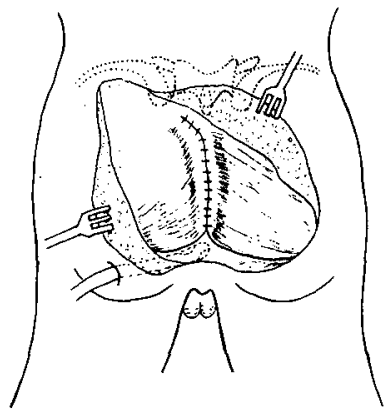

図 6 大臂筇による骨盤底形成 （太いドレーンを 1 本㨂入する）

定されており，仙骨合併切除に際し，両側の仙結節，仙棘 靯带切離による仙骨の授動が肝要となる，仙骨の切断に 入るに先だち，左右仙腸関節下縁を確認しておく，仙疽 切断レベルは, 腹腔側操作により決定された部位で切断 するが，腹腔側レベルと仙骨側レベルを一致させること は必ずしも容易ではない，術前の仙骨X線写真，特に仙 腸関節下縁が仙骨のどのレベルに相当するかを熟知して おくことが肝要と思われる。まず仙骨横断予定線，ま たはその上部で椎弓切除を行う，硬膜は $\mathrm{S}_{2}$ 下縁レベル まで存在すると言われ， $\mathrm{S}_{2-3}$ 以下の仙骨切除では，通 常硬膜の結禁処理は必要ではない，一方硬膜外腔には静 脈丵がみられ，椎弓切除によりある程度の出血は起りう る. 左右の仙骨横断線外縁に示指を扱入し, 腹腔側虽離 層との交通を確認の後, Luers 鋁子，のみと木槌，ある いは線鋸にて一気に仙骨横断を遂行し腹腔側に達する: 仙骨を含めた摘除側を索引すると仙骨横断レベル以下の 仙骨神経が確認されるが，これらを両側にわたり鋭的に 切離する，通常第二仙骨神経まで温存するように努め る. 内閉鎖筋は直視下にその広がりが確認出来, 必要に
応じ合併切除する，最後に膀胱頸部に達し，静脈叢，尿 道の処理を行うと，骨盤内諸臟器と仙骨は en-blockに 切除され，摘除操作は完了する（図 5 , 写真 2 ).骨盤底 に太いドレーンを捚入し，図6のごとく大殿笳起始部を 縫合，後方骨盤底を形成する．皮覤はナイロン系にて縫 合する (写真 3 ).

成續結果（表 2)

症例 6 を除き， 6 例中 5 例根治切除可能があった．仙 骨合併切除に加え，原発直腸癌の症例 $1 ， 2$ には骨盤内 臟器全摘術が行われた。尚, 症例 2 は術前より右そけい リンパ節転移を認め, 仙骨合併骨盤内朦器全 摘術に加 え，一期的に両側の鼠径リンパ節郭清を行った症例であ る. 症例 $3 ， 4 ， 5$ は他院直腸切䉼術後再発例であり， 残存骨盤内臟器全摘術が行われた，症例 6 は，骨盤内藏 器全摘術後に小腸会㓌瘦が発生し，瘦孔閉鎖の目的で開 腹手術が行われたが，その際仙骨前面の再発巣が発見さ れ，仙骨の切除が行われた症例である. 仙骨切除は， 2 例は $\mathrm{S}_{2-3}$ レベルで, 2 例は $\mathrm{S}_{3-4}$ レベルで， 1 例 は $S_{4}$ レベルで，I例は $S_{4-5}$ レベルで切断された. 尿 路変更術式としては，5例に回腸導管造設が 1 例（症例 3）には一側合流尿管皮膚瘦術が施行された. 手術時間 は, 最短 7 時間, 最長 23 時間 (平均12時間 30 分) であっ た。な扔, 症例 3 は, 腹腔側操作時多量出血を来たし, 骨盤腔タンポナーデの後24時間後に再手術を施行した 2 期分割手術例である，出血量は，最少 $1,100 \mathrm{ml}$ ，最大 $26,000 \mathrm{ml}$ (平均 $7,800 \mathrm{ml}$ ) であった. 手術死亡例はない. 術後合併症は症例 3 に腸閉塞と尿管縫合不全, 症例 4 , 6 に骨盤腔澧湟の併発をみたがいずれも治療している。 本術式はここ1〜2年の間にとり入れられたため，十分 な症例の集積と長期にわたる遠隔成績の検討はできな い. 現在 6 症例すべて生存中である. 姑息切除（切除断

表 2 症例の まとめ

\begin{tabular}{|c|c|c|c|c|c|c|c|c|}
\hline 症例 & 初回手術 & 術式と手術日 & 仙骨切離レベル & $\begin{array}{l}\text { 手術時間(hours) } \\
\text { 出 Ifll 量(ml) }\end{array}$ & ，根治性 & 合併症 & そ の 他 & 経 過 \\
\hline 1 & & $\begin{array}{l}\text { TPE } \\
7 / \cdot 83\end{array}$ & $S_{4-5}$ & $\begin{array}{r}7 \\
1100\end{array}$ & 治痹切除 & & . & $\underset{N E D}{12 \operatorname{mos} \text { 生存 }}$ \\
\hline 2 & & $\underset{10 / .83}{\text { TPE }}$ & $\mathrm{S}_{4}$ & $\begin{array}{r}10.5 \\
4100\end{array}$ & 治㹦切除 & & $\begin{array}{c}\text { 両側ソケイイ郭清 } \\
10 \% 83\end{array}$ & $\begin{array}{c}10 \mathrm{mos} \text { 生存 } \\
\text { NED }\end{array}$ \\
\hline 3 & APR & $\begin{array}{l}\mathrm{RPE} \\
4 / \cdot 84\end{array}$ & $\mathrm{~S}_{2-3}$ & $\begin{array}{r}23 \\
26000\end{array}$ & 治瘺切除 & $\begin{array}{l}\text { イレウス } \\
\text { 尿管縫合不全 }\end{array}$ & 二期分割手術 & $3 \underset{N E D}{\operatorname{mas}}$ 生存 \\
\hline 4 & $\mathrm{APR}$ & $\begin{array}{l}\mathrm{RPE} \\
2 /, 84\end{array}$ & $S_{2-3}$ & $\begin{array}{r}15 \\
10000\end{array}$ & 治癒切除 & : 骨盤腔膿瘍 & r & $\begin{array}{c}6 \mathrm{mos} \text { 生存 } \\
\mathrm{NED}\end{array}$ \\
\hline 5 & APR & $\begin{array}{l}\mathrm{RPE} \\
5 / \cdot 83\end{array}$ & $\mathrm{~S}_{3-4}$ & $\begin{array}{r}13 \\
4000\end{array}$ & 治繶切除 & & & $\begin{array}{l}14 \mathrm{mos} \text { 生存 } \\
\text { 局所再発 }\end{array}$ \\
\hline 6 & LAR & $\begin{array}{c}\text { 小腸䝑閉鎖 } \\
6 /, 83\end{array}$ & $S_{3-4}$ & $\begin{array}{r}7 \\
1600\end{array}$ & 姑息切除 & 骨盤腔膿㾤 & $\begin{array}{c}\text { TPE } \\
10 / \cdot 83\end{array}$ & $\begin{array}{l}13 \mathrm{mos} \text { 生存 } \\
\text { 局所再登 } \\
\text { 肺 転 移 }\end{array}$ \\
\hline
\end{tabular}

注：APR：腹会陰式直腸切断術, LAR：低位前方切除術, TPE：骨盤内臓器全摘術

RPE：直腸切断術後の骨盤内臟器全摘術; NED：非担癌生存 

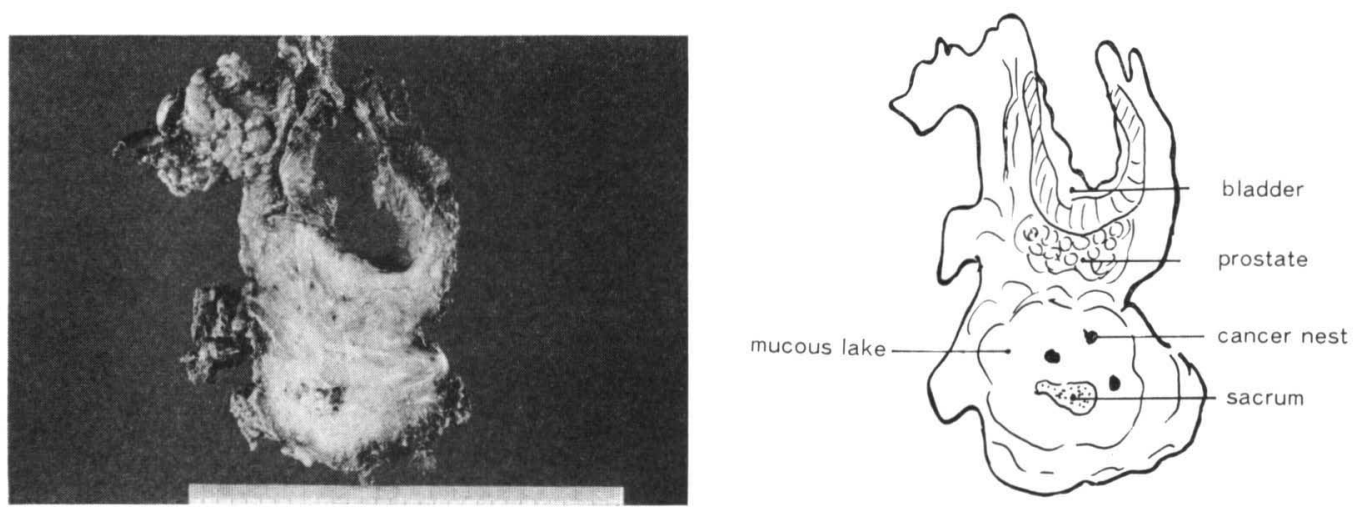

写真 4 症例 4 摘出標本と組織学的再発巣の範囲
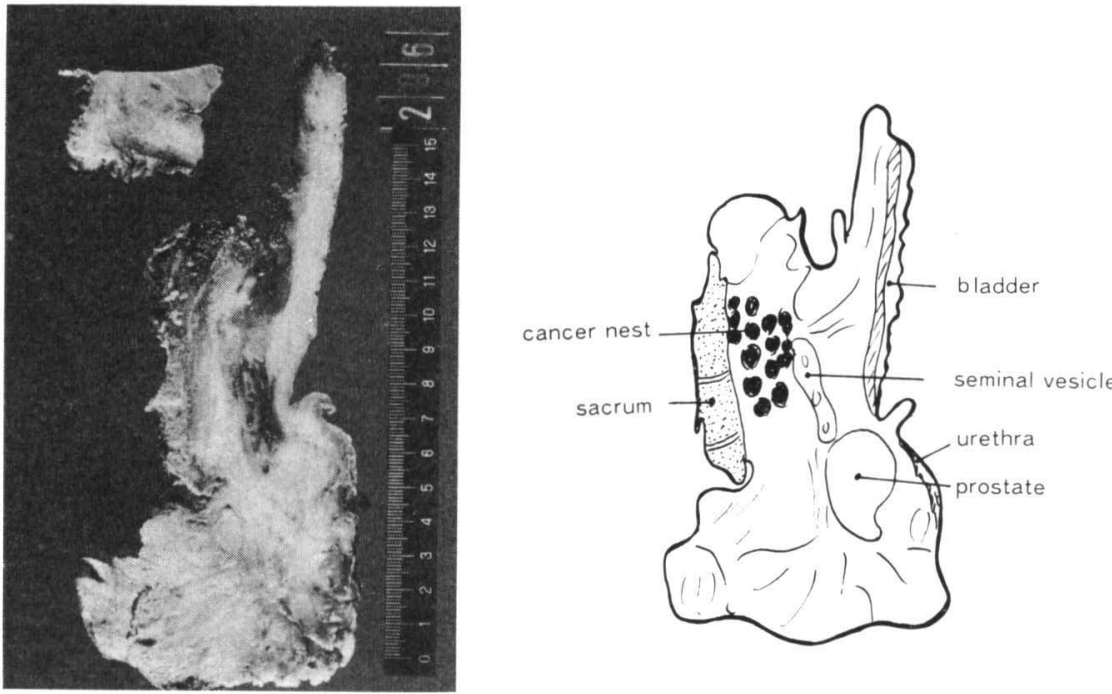

写真 5 症例 6 摘出標本と組織学的再発巣の範囲

端に組織学的に癌巣残存) に終えた症例 6 は, 術後13力 月の現在, 局所再発と多発性肺転移が出現し, 全身化学 療法施行中である。症例 5 は, 術後12力月目に CEA の 上昇と殿部痛が出現し, 局所再発と診断され現在放射線 治療中である. 症例 $1 ， 2 ， 3 ， 4$ は，再発の微候はな く 12 力月, 10 力月, 3 力月, 6 力月生存中である. 切除 標本の病理組織学的検査では, 症例 3，4，6 に仙骨へ の明らかな癌巣の浸潤を認めた (写真 4 ). さらに症例 3 では仙骨のみならず右大殿筋への浸潤も認めた，一方症 例 $1,2,5$ では仙骨への直接浸潤は認めなかったが, 線 維化組織と介して強く仙骨との癒着がみられた(写真 5 )。組織型は分化型腺癌 5 例（高分化 2 例，中分化 3 例）と粘液癌 1 例であった. 次いで症例 $2,3,4$ にっ き詳述する.

\section{症 例 報告}

症例 2：

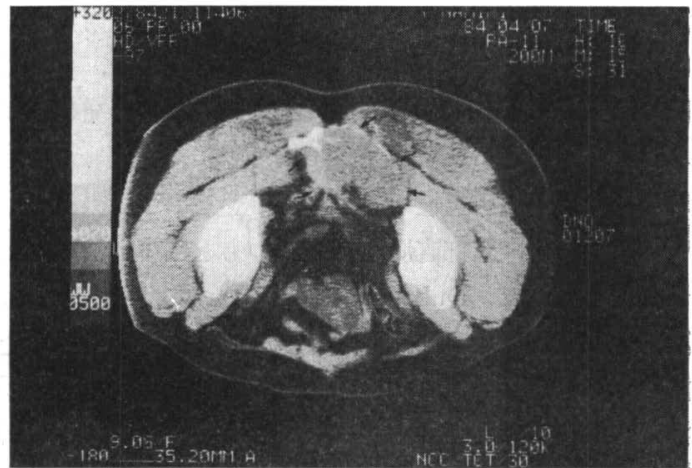

写真 6 症例 3 術前骨盤 $\mathrm{C}$ T像 矢印で囲まれた籁囲に腫瘍影を認める 右侧仙骨は完全に破壤されている

1980年 7 月頃より血便出現するも放置. 血便消失せず 1981年 7 月直腸癌と診断されたが，この時点では手術を 拒否し放射線治療を行うことになった。1982年11月より 


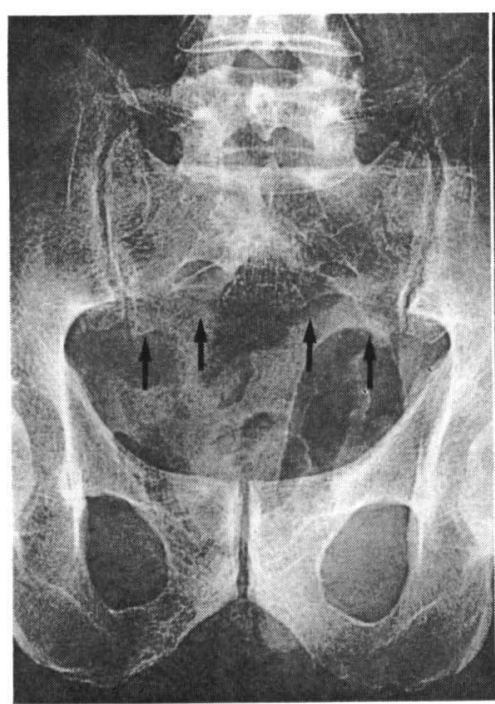

(正 面)

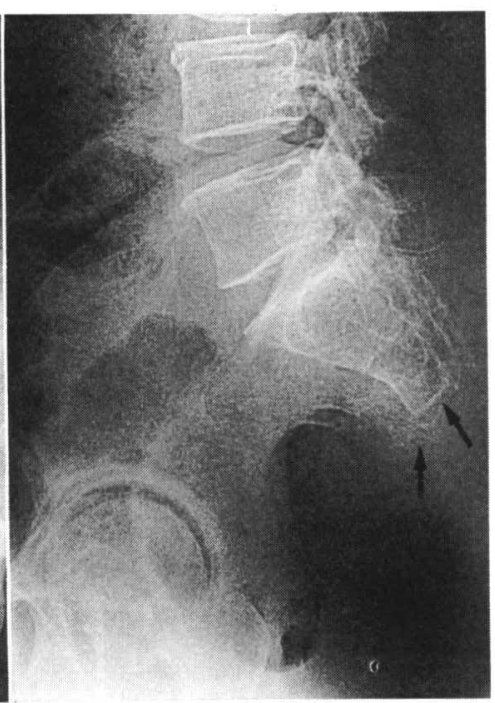

(側 面)

写真 7 症例 4 矢印は仙骨切断レバルを示す. S 3 以下が完全に切除されている.

加温照射治療を計10回行い, 外照射線量として4,000 rad が施行された. 更に直腸腔内照射を計 4 回, 線量にして 2,000rad が追加照射された. しかし1983年 8 月, 放射 線障害による肛門括約筋機能の廃絶, 直腸会陰瘻の形 成, さらに右鼠径リンパ節転移の出現をみ, 患者自身も手 術に対し積極的姿勢と成って来たので，1983年10月仙骨 合併骨盤内臓器全摘術と両側鼠径リンパ節郭清術が施行 された. リンパ節は右292，251にそれぞれ 1 個の転移を 認め, $\mathrm{n}_{2}$ Dukes C 期であった. 切除標本の検索では, 前立腺, 膀胱, 精囊へ直接浸潤が認められたが仙骨への 浸潤はなかった。しかし, 放射線治療と直腸会陰瘦の形 成のため, 仙骨前面のいわゆる Waldyer's fascia は, 高度な線維性疟痕組織に置きかえられていた. 術後経過 は順調で, 患者は40病日目に退院した. 退院後, 3 力月 目より元気に社会復帰し, 術後 9 力月の現在再発の徴候 なく生存中である.

\section{症例 $3: 49$ 歳 男性}

1981年 7 月, 下部直腸癌の診断のもとに腹会陰式直腸 切断術を受けた. Dukes B 期であった. 2 年 5 力月後, 殿部, 仙骨痛が出現, CT 検查の結果仙骨の破壊像を 認め（写真 6 ), 国立がんセンターに紹介された. 仙骨浸 潤を伴う後方骨盤壁再発と診断し，1984年 4 月仙骨合併 骨盤内臓器全摘術が施行された. 手術時, 大動脈分岐部 以下の骨盤内諸臟器は, 硬い線維化㾿痕組織に埋没する 型で存在し，閉鎖腔より内腸骨血管系の処理は困難を極 め, 腹腔側操作のみで約 $16,000 \mathrm{ml}$ の出血を見たため, 24 時間後に仙骨側操作を行うという二期分割手術となっ た. 尚尿路変更術式としては侵襲の少ない一側尿管合流

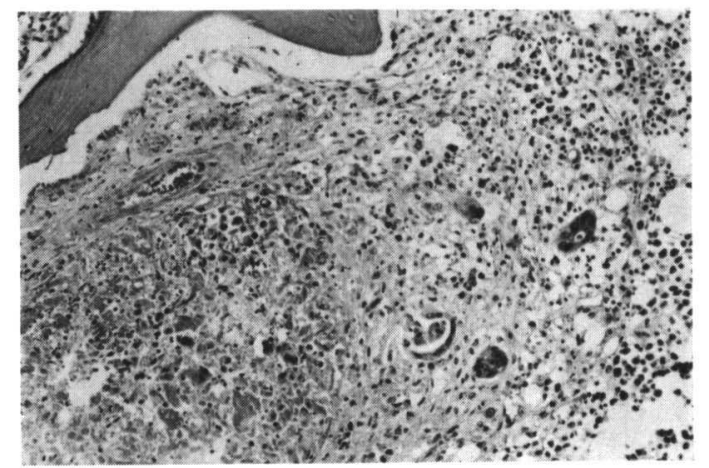

写真 8 症例 4

術前 7,300 rad の放射線治療が行なわれた。 仙骨への浸潤を認め，放治効果は Grade III であった。

皮膚瘻術が採用された. 仙骨は $\mathrm{S}_{2-3}$ レベルで切断され, 右仙骨神経は $S_{2}$ 以下の切除と成った. 右下肢の neurralgia は約 1 力月間持続したが, 歩行については特に 問題はない. 術後腸閉塞と尿管吻合部縫合不全を併発し たが軽快治瘉している. 切除標本の病理組織学的検索で は CT 像に一致化し, 右仙骨への浸潤に加え右大殿筋 への浸潤を認めた。 術前 CEA は $161 \mathrm{ng} / \mathrm{ml}$ と高值を 示したが, 術後 1 週間目には $3.8 \mathrm{ng} / \mathrm{ml}$ と正常值に復し た. 術後 3 力月目の現在外来通院中である.

\section{症例 $4: 54$ 歳 男性}

1975年 5 月, 下部直腸癌の診断のもとに腹会陰式直腸 切断術が施行された. 1982年 4 月, 尾骨痛の出現をみ た. 1983年 2 月会陰創皮下腫瘤の生検の結果, 粘液癌と の組織診断を得, 局所再発が判明した. 1983年11月まで 
に 7,300rad の外照射と, Methothraxate 1.8gr, UFT $1.8 \mathrm{gr}$ 等の全身化学㙩法がなされたが，尾骨痛は改善せ ず，1984年1月国立がんセンターを紹介された．初回手 術より 6 年 8 力月後の1984年 2 月任骨合併骨盤内臟器全 摘術が施行された．仙骨は $\mathrm{S}_{2-9}$ レベルで切断, $\mathrm{S}_{3}$ 以下の 仙骨神経は切除された（写真 7 ). 術後骨盤腔膿瘍の併発 をみたが治渝し，歩行障害むなく術後 6 力月の現在元気 に外来通院中である。切除標本の検索では，下部仙骨は 癌巣にとりかこまれ精褧への浸潤も認められたが，癌巣 の多くは壤死病米であり，極く一部に vialle cancer cell を認めるのみであった（放治効果 Grade III）(写真 8).

\section{考察}

進行大腸癌の再発例の半数近くは局所再発である. 私 共はこれら再発癌の根治的治潦の主役もまた，再度の外 科燎法であると考え，骨盤内臟器全摘術を含む再切除を 積極的に行って来た ${ }^{1,2)}$. 局所再発の中でも肛 門括約筋 温存術後の局所再発では根治的再切除可能な症例飞も結 構遭遇し, 本術式施行後の follow up study の重要性に つきたびたび報告してきだ)。しかし， Miles 術後の局 所再発倍対する再切除の成績は median survival で約 16力月と必ずしも満足すべきものとは言いがたく，Polk の再切除の報告も悲観的なものであっだ． Miles 後局 所再発癌の進展様式をみると，その多くは骨盤壁再発の 型をとって抢り，根治的再切除率は肛阴括約筋温存術後 に比較し極めて低率といわざるを得ない，その理由は， たとえ骨盤内臟器全摘術を施行しても骨盤壁再発巣の不 完全切除という結果に終える症例がほとんどだからであ る. しかし, 根治的再切除が不能であっても, 腫瘍量を 減少させ, 切除不能再発巣の搪がりと, 正確な再発部位 の認定ができ，小線源，加温療法などの，効果的かつ強 力な合併補助療法が可能であるなどの多くのメりットが 西るため，再発癌に対する外科㙩法を私共は積極的に行 っているわけである。

これら骨盤壁再発癌の再切除を施行するなかで，bony pelvis 特に後方骨盤壁の合併切除により根治的切除が 可能であったと考ええる症例にも遭遇していた，1981年 Wanedo ${ }^{51}$ 占法局所再発直腸澏に対し，仙骨合併切除術 式をとり入れ，11例について詳細に報告した，その後わ が国においても仙骨合併切除について高木"() が，また坐 骨の合併切除について前谷》らの 報告をみるに至った。 ところで，Miles 術後の骨盤壁再発には大坐骨孔周辺 で仙骨神経叢に浸潤する型で進展を示す側方骨盤壁再発 と,尾骨，仙骨などへ比較的限局する型で進展を示す後方 骨盤壁再発の 2 型に大きく分類することができよう，前 者, すなわち側方骨盤壁再発の多くの症例は側方りンパ
節転移の不完全郭清の結果であると推論でき, 再発様式 として最む頻度が高い.Wanebo らの論文を精読してみ ると nerve root invasion のみられる一部の症例にも仙 骨合併切除を採用しているが，これら側方骨盤壁再発に 対する本術式の効果については，根治性に疑問があり， 現在のところ私共恃否定的見解をとっている. 一方，後 方骨盤壁再発や一部の原発直腸癌では，本街式の採用に より，はじぬて根治的切除が可能となる. 今回報告した 6 例中 5 例に根治的切除が行われた. 症例 $3 ， 4 ， 5$ で は明らかに仙骨への浸潤がみられ，残りの3 例について も仙骨前面には強い線維性組織や炎症反応がみられ，本 合併切除を採用しなければ癌巣を残す仜険が大きかった ものと推論出来る. 本報告の症例 6 は低位前方切除後の 吻合部近傍再発に対し，骨船内臟器全摘術を施行した。 この時仙骨前面には強い線維肉芽腫様変化を認めたが， 仙骨合併切除は行わなかった. 7 力月後に小腸会陰瘦の 発生をみ再手術を行ったが，この時仙骨前面に再発巣を 認め仙骨合併切除を採用したが，姑息切除に終え大いに 反省させられた症例であった。

ところで，本報告例すべてに骨盤内臓器全摘術が同時 に施行されている．症例 1，2 は，術前術中評価で前立 腺，膀腅などへの直接浸潤が予想されたため，骨盤内臟 器全摘術が施行された。一方, 症例 $3 ， 4 ， 5$ は, 直腸 切断術後の再発であり(いずれも男性)，尿管，膀胱，前 立腺, 精露亦発巣に対し, 直接的な前方諸藏器となっ ていること，また再発癌では，原発值腸癌以上に周囲結 合織内一の進展が高度であることなどの諸点より根治性 を高めるためには尿路系諸藏器の合併切除は不可欠と考 えらる. 加えてWanebo らが，膀胱温存例で指摘し ているように，S2-3レベルで仙骨切除を行えば高度な排 尿，性機能障害は必発と成る，根治性と機能障害の諸点 より Miles 術後の後方骨盤壁再発例住対する再切除術 式として, 残存骨盤内諸臟器の合併切除は不可欠である と言える。

さて，ここで仙骨合併骨盤内臟器全摘術の適応基準を まとめてみたい，一般に骨盤内臟器全摘術の適応基淮と して，(1) リンパ節転移を含的て病巣が骨盤内に限局し ていること，(2) 下肢の浮腫のないこと，(3) 坐骨神経 痛など仙骨神経叢への浸潤所見のないこと，(4) 骨盤外 层管に閉塞所見のないこと，(5) 遠隔転移のないこと， 以上の諸基準が挙げられている。（2）(3)は，腸骨血管 系，特に外腸管に沿うリンパ系の閉塞と側方骨盤壁浸潤 の存在を示唆する所見である. 仙骨の high amputation により，骨盤内諸蔽器を含む一部の倒方骨盤壁再発に は，たしかに有効な術式と言えるかもしれないが，側方 骨盤壁再発への本術式の採用については，先述したごと 
く，私共は否定的見解をとっている．そこで，本術式の 適応基淮として，(1)～(5) まで骨盤内臓器全摘術の適応 基準に加え，癌夈が後方骨盤壁すなわち尾肖，仙骨に浸 潤ないしはその疑いの濃厚な症例に対し，仙骨合併骨盤 内臓器全摘術の真の適応があると考える.

仙骨切除術式の歴史を簡単にふりかえってみると， 仙骨原発の骨腫瘍や仙骨にかかわる欶部腫婸に対する 術式として，整形外科領域で 採用され詳細な 報告は， Bowers (1984) $)^{8)}$ の仙骨原発巨細胞腫に施行された 1 例 にはじまる.1978年 Stener9)らは，本術式の適応，手術 手技，少後機能障害について詳述し，仙骨の high amputationに関連した各種機能障害を（1）排尿・性機能 障害，（2）排便，肛門機能障害，(3) 骨盤の安定性と下 肢の運動機能障害の三点につき，仙骨切断レベルとの関 連において検討している. 進行直腸癌や再発直腸癌への 本術式の採用では，根治性を高める目的で骨盤内臟器全 摘術が同時に施行されて招り，(1)（2）についての具体 的対策は，ストーマリハビリテーションの充実であると いえる，そこで最も問題となる術後機能障害は，骨盤の 安定性と下肢の運動機能障害である，high amputation の手技上の問題として $\mathrm{S}_{1}$ 近傍での仙骨切断を行うと脊 髄液の漏出が起るが，この場合は硬膜を water-tight に 縫合すればよい，S 1 が温存されていれば骨然及び下肢 の instabiliy は生じない，今回報告した 6 症例の仙骨レ ベルの最高は $\mathrm{S}_{2-3}$ であり，硬膜の処理や骨盤および下 肢の instabilityの問題は，いずれの症例においても生 じていない，次いで，仙骨神経切除に伴う運動障害の問 題である. Stener および Gunterberg ${ }^{10)}$ は，S仙骨神経 が温存されれば歩行障害は特に生じないと述べている. ところで，仙骨切除螌囲は仙骨切断レベルに勿論規定さ れる. 症例 3，4は S2-3 レベルにて仙骨合併切除が行 われ，症例 4 は $\mathrm{S}_{3}$ 仙骨神経以下が切除され，症例 3 で は $S_{2}$ 仙骨神経以下が合併切除されたが，特に歩行障害 は起っていない。

仙骨合併骨盤内藏器全摘術は極めて大きな手術侵襲を 伴ら術式である. 6 症例の平均手術時間は, 12 時間30分， 出血量 $7,800 \mathrm{ml}$ であった. 手術の必要性と侵襲の程 度 につき，患者およびその家族に十分説明し了解を得るこ とは，本術式に望むにあたり極めて大切な事項である。 また術前臨床所見の正確な把握，骨盤 X-P，特に仙骨 レントゲン写真, 骨盤 CT 像の熟読は不可久かつ重要 な事項であることは論をまたない，

最後に手術効果を検討してみたい，術前強く訴えてい た会㓌部痛や殿部痛の改善が認められ，いずれの症例に おいても歩行障害は生じていない，手術侵襲は過大なも のではあるが，手術の直接効果すなわち短期效果は十分
期待しうる術式と言える．かかる意味で局所進展高度な 進行直腸癌や局所再発直腸癌に詨し合理性のある納得出 来る術式といえる，むちろん長期にわたる遠隔成績を検 討する中で，術式に対する真の評洒をしなけれ讪ならな いが，まだ遠隔成績を論ずるだけの症例の集積を持たな い. 今後，症例党重放值腸癌に対する外科治療体系にお ける本術式の位置付けを明確にしてゅきたいと考えてい る.

\section{ま と め}

（1）原発直腸癌，局所再発直腸癌に対し，仙骨合併骨 盤内藏器全摘術が施行された 6 症例を報告した。?

(2) 通常の骨盤内䑏器全摘術の適応基準に加え，後方 骨盤壁浸潤の存在する症例に対して採用されるべき術式 と考えられた。

（3） 6 症例の経験をもとに，本術式の手術手技につい ても言及した.

（4）本術式の手術侵襲は過大なものであるが，臨床症 状の改善をもたらし，根治性の高い合理的術式であると 考えられた．今後は，長期にわたる遠隔成績を検討する 中で直腸癌外科治潦体系における本術式の位置付けを明 確にしてゅきたいと考えている.

稿を終えるに当り，研究所病理部，広田映五博士抢上 び手術に御協力いただいた麻醉科医師，輸処管理室の諸 兄に謝辞を表します。

\section{文献}

1）森谷冝皓，小山靖卡，北條慶一ほ加：進行大腸 癌に対する集学的治療一肺転移切除と直晹癌骨盤壁再発に対する小線源，加温療法一日消外会 誌 $16: 1847-1851,1983$

2）森谷宜皓：進行大腸癌に対する集学的治療一邀 隔転移坚切除の治療成績々進行面腸憈治療にお ける骨盤外科の特殊性一外科㟝療 $25: 1146-$ 1155,1983

3) Moriya Y, Koyama K, Hojo K, et al : Local recurrence after sphincter-saving procedures for carcinoma of the rertum: an analysis of 141 cases. Jpn J Clin Oncol $10: 265-$ 272, 1980

4) Polk HC Jc, Spratt JS Jr: The results of treatment of perineal recurrence of cancer of the rertum. Cancer $43: 952-955,1979$

5) Wanebo HJ, Marcove RC: Abdominal sacral resection of locally recurrent rectal cancer. Ann Surg $194: 458-471,1981$

6) Takagi H, Morimoto $T$, Kato $T$, et al : Pelvic exenteration combined with sacral resection for recurrent rectal cancer. J Surg Oncol 24:161-166, 1983

7）前谷俊三，飯島庸介，内藤厚司结加：骨盤内灆 
上骨盤壁の㹡大合併切除一手術 $38: 637-644$, 1984

8) Bowers RF : Giant cell tumor of the sacrum. A case report. Ann Surg $128: 1164-$ 1172,1948

9) Stener B, Gunterberg B : High amputation of the sacrum for extirpation of tumors.
Principles and technique. Spine $3: 351-366$, 1978

10) Gunterberg B, Kewenter J, Petersén I, et al: Anorectal function after major resections of the sacrum with bilateral or unilateral sacrifice of sacral nerves. $\mathrm{Br} \mathrm{J}$ Surg $63: 546-554,1976$

\title{
Total Pelvic Exenteration Combined with Sacral Resection for Primary and Recurrent Rectal Cancer - A Report of Six Cases with Special Reference to Indications and Surgical Techniques
}

\author{
Y. Moriya, Y. Koyama, K. Hojo, H. Shimizu and H. Dozono \\ Department of Surgery, National Cancer Center Hospiral, Tokyo
}

Primary far advanced and locally recurrent rectal cancer with involvement of the posterior bony pelvis are rarely amenable to conventional resection, including pelvic exenteration. We have performed total pelvic exenteration combined with sacral resection which permits a complete enbloc excision of pelvic organs, recurrent tumors and the posterior bony pelvis. Six patients were submitted to this procedures. The operation time was seven to 23 hours, aueraging 12.5 hours, and the blood loss averaged $7.800 \mathrm{ml},(1.100 \mathrm{ml}$ to $26.000 \mathrm{ml})$. The transected level of the sacrum was $\$ 2-3$ in two patients, S3-4 in one, and S4-5 in one. Four patients are living free of disease at three, six, 10, and 12 months. The other two are living with disease at 13 and 14 months. Although this report concerns a very small series, it suggsts that total pelvic exenteration combined with sacral resection is an adequate and reasonable procedure for locally for advanced primary and recurrent rectal cancer.

(昭和59年 7 月 20 日受付) 